\title{
An Examination of Individualism within Employee Help-Seeking Networks
}

\author{
Randall P. Settoon (Corresponding author) \\ Department of Management, Southeastern Louisiana University \\ SLU Box 10813, Hammond, Louisiana, 70402, United States \\ Sang H. Lee \\ Department of Business Administration, Southeastern Louisiana University \\ SLU Box 10813, Hammond, Louisiana, 70402, United States
}

Received: Aug. 12, 2018 Accepted: Sep. 10, 2018 Online published: Sep. 17, 2018

doi:10.5296/ijhrs.v8i4.13490 URL: https://doi.org/10.5296/ijhrs.v8i4.13490

\begin{abstract}
Prior research focusing on the impact of individualistic orientations on the performance of cooperative behaviors has produced mixed results. Researchers have concluded that the self-focused orientation of individualists will lead them to be less cooperative than others. On the other hand, some scholars have argued that helping others is core to individualists' self-concept and that competently assuming the role of help-giver is a source of intrinsic satisfaction. In this study, we test this proposition by examining individualistic orientations within employee help-seeking networks. Results from a sample of 107 employees within a regional medical center indicate that the level of individualism in helping-seeking networks is positively associated with help-seekers' perceptions of support. Further, the results suggest that the relationship is stronger in dense networks. Implications of this work and directions for future research are discussed.
\end{abstract}

Keywords: relational identity orientation, employee individualism; help-seeking networks

\section{Introduction}

Organizations are dependent on employees to subordinate their self-interests and take a genuine interest in the success of their coworkers. To a large degree, an employee's ability to meet deadlines, resolve unexpected performance contingencies, and remain engaged at work is dependent on the willingness of coworkers to help. Perhaps this explains the amount of research attention devoted to understanding the relationship between employee individualism 
and cooperative engagement (e.g., Moorman and Blakely, 1995; Van Dyne, Vandewalle, Kostova, Latham, \& Cummings, 2000; Kirkman \& Shapiro, 2000). Studies have shown individualists to produce value within organizations through personal initiative, high levels of motivation, and creative problem-solving (e.g., Goncalo \& Staw, 2006). However, their preference for independence, self-reliance, and individual achievement is understood to be incompatible with contexts requiring an other-focused orientation (see Gundlach, Zivnuska, \& Stoner, 2006). Individualists view such contexts as burdensome and an obstacle in their pursuit of personal goals (Oyserman, Coon, \& Kemmelmeier, 2002).

An implication of these findings for informal employee networks is that individualists may locate themselves as a dispassionate node, thereby restricting the flow of resources, or otherwise cause them to move through circuitous routes. As much as an other-oriented focus can create trusting connections that facilitate the sharing of information, positive sentiment, and other vital tangible and intangible resources, a self-focused orientation can engender more calculative interactions that serve self-interests. One need look no further than the organizational citizenship behavior literature for perspective on the potential negative impact of individualism (Bolino, Turnley, and Bloodgood, 2002; Moorman \& Blakely, 1995). Given the highly individualistic, competitive, and often political climate within organizations, the potential of an employee's networked resources will be limited to the extent that his or her connections reflect individualistic orientations.

In this study, we examine individualism within employee help-seeking networks. Help-seeking networks represent a potential for access to high-quality, valued resources that can be deployed to address performance-related contingencies (Adler \& Kwon, 2002; Coleman 1990). As such, employees are dependent on their network of help-givers to willingly interact with them, to share resources, and to go above and beyond formal job requirements to help them when they have a need (Bolino et al., 2002). By definition, help-seeking networks are collaborative environments, and as a result, are a highly relevant context for studying the relationship between individualism and cooperative engagement.

The use of help-seeking networks in this study provides an opportunity to address a limitation of prior research investigating helping behavior in organizations. Specifically, research has been guided by an assumption that help-recipients are passive in help-givers' decisions to help. However, this is not always the case. Helping interactions between two employees are mostly initiated by help-seekers (Bamberger, 2009). In other words, while some employees provide help and assistance spontaneously, individualists are less forthcoming and give help after it has been solicited (e.g., Anderson \& Williams, 1996). Because individualists are "selectively cooperative" rather than "generally uncooperative," conclusions based on studies examining individualism and help-giving are limited by the extent to which the help-seeking context was accounted for (Bowler \& Brass, 2006).

Theory and research on identity orientation (Ashforth, 2001; Flynn, 2005) have provided a foundation for understanding how and when an employee's social context will influence identity orientation shifts; a shift from one that focuses on individualistic pursuits to one that incorporates a concern for the interests of others. The latter is viewed as essential for the 
development of high-quality interpersonal relationships, and thereby a source of value in employee networks. Also, identity theory informs the current study by suggesting that individuals' self-focused and other-focused orientations are malleable, and that salient characteristics of the situation will prime one or the other. As will be discussed, we propose that features of help-seeking networks prime a relational identity orientation for individualists, thereby providing the basis for the performance of other-oriented behaviors such as help-giving. Below, we provide a brief overview of theory on identity orientation, and then use the identity framework to organize our review of the findings of research on individualism and cooperative behavior.

\subsection{Identity Orientation, Individualism and Cooperative Engagement}

Organizational researchers have pointed to the concept of identity orientation as a theoretical foundation for explaining how an individual's self-focused orientation translates into other-focused behaviors (Ashforth, 2001; Flynn, 2005). Identity orientations assist individuals in defining themselves in relation to others by situating them in a given context (Alpert, Ashforth, \& Dutton, 2000). They serve as bases for evaluating self-esteem and self-worth, for processing information related to one's self-concept, and for guiding behavior in social interaction. Identity orientation has been found to be important for understanding employees' willingness to interact and cooperate with others (Chatman \& Flynn, 2001; Dukerich, Golden, \& Shortell, 2002; Flynn, Chatman, \& Spataro, 2001).

According to Brewer and Gardner (1996), people adopt both a personal identity and a relational identity to represent the self. Personal identity is characterized by a tendency toward protecting, maintaining, and elevating the individual self, whereas relational identity tends toward establishing and maintaining stable interpersonal relationships, protecting and enhancing them, and resisting their dissolution. Of relevance to this study is research finding that one or the other identity is accessible and potent based on characteristics of the social context, such as norm salience and/or role importance (Brewer \& Gardner, 1996; Flynn, 2005; Sluss \& Ashforth, 2007).

\subsection{Individualism and the Primacy of Personal Identity}

By definition, individualism implies an active personal identity that is positioned near the core of an individual's self-system. Individualists treat the self as the most meaningful social unit, place a high priority on achieving personal goals, and thrive in contexts that promote independence, self-reliance, and recognition of personal achievement (Oyserman et al., 2002). Some researchers have concluded that individualists make collective action more difficult because they are less inclined to collaborate or to build strong ties with others; ties that are essential for the emergence of cohesiveness and unity within groups (e.g., Earley, 1993; Gelfand, Triandis, \& Chan, 1996). A considerable amount of research has investigated interpersonal helping in organizations (see Ocampo, Acedillo, Bacunador, Balo, et al., 2018), finding them to enable effective group functioning (e.g., Liu, Chen, \& Holley, 2017) and high-quality dyadic exchange relationships (e.g., Settoon, Bennett \& Liden, 1996; Shore \& Wayne, 1993). As might be expected, however, individualists have been shown to be less likely than collectivists to help others (e.g., Moorman \& Blakely, 1995). These findings aren't 
surprising given that helping interactions are imbued by an other-focused, prosocial orientation, and benefits accrue to the recipient of help at the expense of the giver. Further, the construct domain of helping behavior overlaps somewhat with that of altruism, which implies a belief system that honors selflessness, sacrifice, and a subordination of self-interests to others' interests.

An underlying premise of these studies is that helping relationships are incompatible with the worldview of individualists who may see them as personally costly and a distraction in the pursuit of self-interests (Oyserman et al., 2002). Indeed, helping interactions can be materially, socially, and psychologically costly (Bamberger, 2009). Help-givers run the risk of becoming entangled in a prolonged, untenable helping relationship that requires higher levels of emotional investment, time, and resources than originally anticipated (Bolino \& Turnley, 2005). While tangible benefits accrue to help-seekers (e.g., problem-resolution), benefits for help-givers are uncertain (e.g., low probability of equally valued reciprocity). The implication of these studies for informal networks is that employees whose help-seeking connections are colored by individualism can expect lower levels of support. In other words, the value of the network in terms of cooperative engagement is minimized because help-givers are most focused on managing the personal risks of interpersonal interaction (Flynn, 2005).

Other studies, however, suggest that individualists will be cooperatively engaged when the structure of work processes incentivize it (Allik \& Realo, 2004; Kirkman \& Shapiro, 1997; Wagner, 1995), or when doing so is instrumental for achieving personal goals (e.g., Batson, 1994; Clary \& Snyder, 1999; Schroeder, Penner, Dovidio, \& Piliavin, 1995). Helping behavior has been found to be positively related to performance evaluations and career advancement (Podsakoff, Whiting, Podsakoff \& Blume, 2009). As such, individualists are likely to place a high priority on helping others, albeit for self-interested reasons (Bowler \& Brass, 2006). Additionally, individualists are creative problem-solvers, achievement-oriented, and confident in their own abilities (Baer, Oldham, \& Cummings, 2003; Kirton, 1989; Triandis, 1995). They tend to establish connections with others that span work groups and units across the organization, and as a result, possess information that can provide unique perspectives on problems (Granovetter, 1973). Because their personal talents align with the function of helping interactions (i.e., resolution of help-seeker problems), it is likely that individualists will be effective help-givers and a source of self-esteem. Further, helping interactions are likely to be attractive as they provide opportunities for impression management (Bowler \& Brass, 2006).

In sum, the findings of these studies suggest that individualism is associated with cooperative engagement, but is limited by the extent to which incentives address self-interests. Help-seeking networks provide rich opportunities for achieving personal goals, and individualism will sustain cooperative engagement within help-seeking networks. For help-seekers, levels of perceived support are enhanced when their help-seeking network reflects access to intangible resources, such as the motivation and competence of the complement of help-givers. Such intangible resources enable the mobilization of information, advice, and effort when help-seekers become overwhelmed by increased responsibilities, unexpected demands and other problems affecting their performance. Employees will sustain 
the network connections that are viable in order to mitigate the potential costs of ineffective help, such as exposing a personal weakness to others, assuming a position of vulnerability, or being perceived as incompetent (e.g., Ames \& Lau, 1982). Because help-seeking networks are salient, incentive-laden contexts that prime individualists' personal identity orientation, we hypothesize:

Hypothesis 1: The level of individualism within an employee's help-seeking network will be positively associated with that employee's perception of support.

\subsection{Relational Identity Orientation and Help-Seeking Network Density}

Relational identities are derived from connections and role relationships with others (Sluss \& Ashforth, 2007). They are rooted in dyadic relations (e.g., supervisor-subordinate, mentor-protege), but are also based on the network of such dyadic relationships within which they are enmeshed (Brewer \& Gardner, 1996). Self-worth is evaluated in light of fulfilling roles with appropriate behavior and maintaining stable and satisfying bonds. People who identify at the relational level are motivated to benefit those with whom they have connections and are willing to assume the risks associated with interpersonal interaction (Flynn, 2005).

Although personal identity is closely linked to an individualist's motivational core, researchers suggest that salient features of the task environment can prime a relational identity by changing an individual's sense of independence (Brickson, 2000; Gardner, Gabriel, \& Hochschild, 2002; Kirkman \& Shapiro, 1997; Wagner, 1995). For example, Ramamoorthy and Flood (2004) observed that individualists frequently engaged in helping behavior when their work tasks were highly interdependent with the tasks of coworkers. Such task environments require employees to share information, resources, and support in order to successfully achieve their own performance goals.

Defined by the goals, values, beliefs, and norms associated with a role, relational identities derived from roles and role-based relationships bind networks of role incumbents together into a productive social system (Ashforth, 2001). Some scholars argue that helping others is a matter of personal responsibility for individualists, and the role of help-giver is an element of their relational identity (Schwartz, 1990; Triandis, 1995). In contexts where the roles of "volunteer," "benefactor," or "duty to others" are salient, behaviors aligned with the role-standards will be enacted and serve as a means of judging self-worth.

We propose that the salient role-based relationship characterizing help-seeking networks (i.e., help-giver/help-seeker) will prime individualists' relational identity and motivate them to effectively fulfill the role of help-giver in order to enhance their self-concept (Brewer \& Gardner, 1996; Markus \& Kitayama, 1991). Goals for personal achievement will align with the role (e.g., "I am a help-giver. My coworkers depend on me to help them when they are in need") and rewards such as enhanced self-worth will be judged according to the fulfillment of role-specific expectations (Haslam, Powell \& Turner, 2000; Hogg \& Terry, 2000). Individualists will frame the risks associated with helping interactions in terms of the personal costs associated with not meeting their duty to others. 
Increased interaction strengthens relational identity and reinforces a sense of common identity (Brewer \& Gardner, 1996; Flynn, 2005). Research has shown that higher levels of network density - which is a structural feature indicating the level of connectedness between individuals in a network - is associated with perceptions of belonging and high levels of resource sharing and cooperation (e.g., Oh, Chung, \& Labianca, 2004; Lawler \& Yoon, 1993; Reagans \& Zuckerman, 2001; Sparrowe, Liden, Wayne, \& Kraimer, 2001). For help-seeking networks, we propose that repeated interactions are an indicator of successful helping. Through repeated interaction, individuals gain knowledge about each other's resources and needs, an understanding of mitigating factors affecting successful helping, and the measures taken by others to help. This knowledge aids in a greater understanding among the network of help-givers of the importance to be responsive to others. Finally, increased interaction with other help-givers in an employee's help-seeking network will increase the salience of the help-giving role, expectations for behavior as per those roles, and an enhanced sense of mutualism (Blumer, 1969; Leana \& Van Buren, 1999; Hosking, Dachler, \& Gergen, 1995).

In sum, the salience of the role-based help-giving relationship in help-seeking networks will prime individualists' relational identity orientation. Further, in dense help-seeking networks where interaction among help-givers is increased, the relational identity orientation will be amplified. We hypothesize:

Hypothesis 2: The density of an employee's help-seeking network will moderate the relationship between the level of help-givers' individualism and the employee's perception of support, such that the more dense the network, the stronger the relationship.

\section{Method}

Data for this study were collected from a regional medical center in the southern United States. Employees provided self-reported and sociometric data through a survey that was distributed to them by the researchers. Surveys were completed and returned to researchers in a postage-paid envelope. Overall, 374 surveys were administered and 253 were returned. A total of 215 surveys contained complete data for an effective response rate of $58 \%$. Respondents were from 50 departments in the hospital. The response rate within departments ranged from $17 \%$ to $100 \%$. Seventy-one percent of employees returning surveys were female, the average age was 37.5 years, and the average organizational tenure was 5.4 years.

\subsection{Measures}

Social network analysis provides a means to analyze the pattern of connections linking individuals, and a way to evaluate the interdependencies of behavior and attitudes as related to the configuration of those configurations. Two methods for investigating network data are the "whole" network method and the "ego" network method. Whole network analysis focuses on features of overall network structure and evaluates patterns of ties in entire populations. Alternatively, the ego network method focuses on the ties between an individual (i.e., ego) and those with whom the individual has a direct connection (i.e., alter). In the current study, we employ an ego network approach. 
Ego network models focus on the composition and structure of an ego's network as predictors of individual-level outcome variables in multivariate regression models. Characteristics of network alters as a group are reflective of network composition, and characteristics of the overall pattern of dyadic connections among ego and alters reflect network structure. In the current study, we use the mean of alters' self-reported scores on the measure of individualism as the compositional attribute of interest. Network density was calculated using an algorithm provided with UCINET (Borgatti, Everett, \& Freeman, 2002) and represents the structural attribute in the study. As will be discussed in the following paragraphs, help-seeking ego networks for each employee were analyzed whereby each employee in the study is a help-seeker with their own connections to coworkers from whom they seek help.

We constructed directed, help-seeking networks for each employee from their responses to a sociometric question on the survey. Specifically, employees were asked to list up to five coworkers from whom they seek help when they have problems at work. A total of 347 unique employee names were listed as help-givers by employees whose surveys contained complete information. Using these names, an initial 347 x 347 directed, binary adjacency matrix was created to reflect the presence or absence of a help-seeking tie. Each cell in the matrix contained either a " 1 " indicating that a focal employee (row of matrix) sought help from a particular coworker (column of matrix), or a " 0 " indicating that no help-seeking relationship exists. Because data provided by employees on returned surveys were used to calculate alter composition variables, the adjacency matrix was filtered to exclude employees who were named as a help-giver, but who did not complete a survey. The resulting 215 x 215 adjacency matrix served as the basis for network calculations.

\subsubsection{Dependent Variable}

Perceived Coworker Support. Perceived coworker support represents employees' beliefs concerning the extent of care and support they receive from their social networks (Rhoades \& Eisenberger, 2002; Zimet, Dahlem, Zimet, \& Farley, 1988). In the present study, an employees' perceptions of coworker support was used as the indicator of an employees' evaluation of the extent to which their network alters provide assistance, and as a result, meet the needs for which they seek help (Iverson, 1999). We developed a measure based on Eisenberger, Huntington, Hutchison, and Sowa's (1986) perceived organizational support scale $(\alpha=.82)$. We reworded items so that the referent was the responding employee's coworkers.

\subsubsection{Independent Variable}

Network Alter Individualism. Research has found individualism to be theoretically and empirically distinct across various levels of analyses and has received attention as an individual-level variable reflecting differences within people (Marcus \& Le, 2013; Triandis, 1995; Wagner, 1995). Network alter characteristics are compositional descriptors of an employee's ego network. For continuous alter attributes such as Likert-type response sets, the composition of the ego network is typically summarized using a measure of central tendency (Perry, Pescosolido, \& Borgatti, 2018). We used three items from the Supremacy of Individual Interest subscale of Wagner (1995) to measure the value placed on individualism by network alters (e.g., "Work groups are more efficient when its members do what they 
think is best rather than doing what the group wants them to do"). Alpha reliability was .71. To create the composite measure, we averaged scores on this scale across network alters.

\subsubsection{Moderator Variable}

Network Density. The density of a network is a measure of the number of connections (i.e., dyadic ties) among network members compared to the maximum connections that are possible (Wasserman \& Faust, 1994). It represents the extent to which group members are highly interconnected and embedded in the network. For directed networks, density is the result of the formula $\mathrm{L} /(\mathrm{N}(\mathrm{N}-1))$, where $\mathrm{L}$ is the number of established ties between network members (i.e., between ego and alters, and between alters) and $\mathrm{N}$ is the total number of possible ties if all network members were connected. The higher the proportion, the more dense the network, and the more interconnected are members (Kilduff \& Tsai, 2003). Density can vary from 0 to a maximum of 1 , where a value of " 1 " would indicate that all members have mutual connections with all others in the network.

\subsubsection{Control Variables}

Network Alter Affect-Based Trust. Connections between individualists and coworkers are proposed to resemble negotiated exchange (Flynn, 2005), which are exchanges that are generally void of affect and exist to generate rewards attached to achieving a performance goal (i.e., problem resolution). On other hand, much research has found help-giving to be an outcome of interpersonal connections based on high-quality, social exchange. Social exchange differs from negotiated exchange as parties repeatedly and voluntarily incur personal costs to help each other without an expectation of a contingent quid-pro-quo (such as those between close friends, family, etc.). An over-arching belief in the intrinsic virtue of the relationship is the primary reward for the help-giver, and as each party trusts that the other will dependably act in their best interest, the connection is strengthened (e.g., Konovsky \& Pugh, 1994; Shore \& Wayne, 1993). This form of exchange relationship is considered high-quality because the connection is infused with socio-emotional elements. Affect-based trust is a feature of social exchange relationships, and it has been found to be an antecedent of help-giving behavior. To the extent that the calculative motives of individualists are present as hypothesized, individualism should explain variance in perceptions of support beyond that explained by affect-based trust.

Affect-based trust was measured using McAllister's (1995) Affect-Based Trust Scale (e.g., "My coworkers and I have a sharing relationship. We freely share our ideas, feelings, and hopes"). This five-item measure exhibited good psychometric properties $(\alpha=.85)$ and has been found to be associated with high-quality, social exchange relationships (see McAllister, 1995). As we did with alters' scores on the measure of individualism, we averaged scores on this scale across alters to create an indicator of the level of affect-based trust embedded in the network.

Help-Seeker Job Satisfaction. Job satisfaction is defined as a pleasurable or positive emotional state resulting from the appraisal of one's job or job experiences (Locke, 1976). It has been found to be correlated with a number of variables that reflect an individual's "experience of work" and quality of working life. We used job satisfaction as a control for the 
possibility that help-seekers' perceptions of support are based on positive evaluations of the work environment rather than evaluations of the level of support received from coworkers. We used a four-item general job satisfaction measure $(\alpha=.79)$. This measure comprised two items from the Michigan Organizational Assessment Questionnaire (Cammann, Fichman, Jenkins, \& Klesh, 1983) and two items from Brayfield and Rothe's (1951) index.

Help-Seeker Demographics. Research suggests that help-seekers' demographic variables could present potential confounds in our study (e.g., Lee, 1997). For example, employees with longer duration in the workplace (i.e., tenure) may have more established, mature ties within their help-seeking networks as compared to those employees with shorter duration. Other research has found individuals with higher socio-economic status - typically operationalized in terms of education - are more likely to seek help and do so more frequently than those associated with lower socio-economic strata (Fischer, Winer, \& Abramowitz, 1983; Nadler, 1998). As such, we controlled for variance due to help-seekers' tenure and education level so that we could better evaluate the effects of network individualism. Education level was assessed via a 3 -point scale $(1=$ high school degree, $2=$ college degree, 3 = graduate degree) and tenure was measured through employees' responses to the question "How many years have you been employed at the hospital?"

\section{Results}

The smallest social structure appropriate for empirically investigating theoretical relationships within groups is the triad. After extracting each employee's help-seeking network, we identified those having two or less nodes (i.e., two nodes would represent a dyad) and excluded them from analysis. The resulting sample size was $N=107$. Table 1 contains descriptive statistics and bivariate correlations for the study's variables. To test the hypotheses, we conducted a moderated hierarchical regression analysis. All variables were mean-centered to control for the possibility of multicollinearity due to the inclusion of an interaction term (Aiken \& West, 1991). In our regression analysis, we proceeded as follows. In Step 1, we regressed the dependent variables on the control variables. In Step 2, we included the control variables from Step 1 and added the independent variable (i.e., network individualism) and the hypothesized moderator variable (i.e., network density). In Step 3, all study variables were entered, including the product of the centered individualism and network density measure (i.e., the interaction term). The standardized regression coefficients and model statistics are presented in Table 2.

Table 1. Means, Standard Deviations, and Correlations

\begin{tabular}{|c|c|c|c|c|c|c|c|c|c|}
\hline & $M$ & $S D$ & 1 & 2 & 3 & 4 & 5 & 6 & 7 \\
\hline \multicolumn{10}{|l|}{ Help-Seeker } \\
\hline 1. Perceived Support & 3.77 & .50 & $(.82)$ & & & & & & \\
\hline 2. Tenure & 4.83 & 4.44 & .00 & -- & & & & & \\
\hline 3. Education Level & 1.93 & 1.12 & -.06 & -.10 & -- & & & & \\
\hline 4. Job Satisfaction & 4.20 & .57 & $.19 *$ & -.06 & .07 & $(.79)$ & & & \\
\hline \multicolumn{10}{|l|}{ Network Composition } \\
\hline 5. Alter Affect-Based Trust & 3.75 & .31 & $.18+$ & .06 & -.07 & -.13 & $(.85)$ & & \\
\hline 6. Alter Individualism & 2.40 & .49 & $.24 *$ & .09 & -.05 & .04 & .07 & $(.71)$ & \\
\hline \multicolumn{10}{|l|}{ Network Structure } \\
\hline 7. Density & .26 & .22 & -.03 & .06 & .05 & $-.22 *$ & $.21 *$ & -.02 & -- \\
\hline
\end{tabular}


$\mathrm{N}=107$. Cronbach's alpha presented in diagonal for multi-item scales.

$+\mathrm{p}<0.10 ; * \mathrm{p}<0.05 ; * \mathrm{p}<0.01$.

In support of Hypothesis 1, the level of network individualism predicted help-seekers' perceptions of support (Step 2: $B=.22, t=2.34, p<.05$ ). The regression coefficient was statistically significant and positive. Although not hypothesized, network individualism explained variance in help-seekers' level of perceived support above and beyond variance explained by network affect-based trust, providing support for negotiated exchange as the form of connection preferred by individualists (Flynn, 2005).

Table 2. Hierarchical Moderated Regression

\begin{tabular}{lccc}
\hline & \multicolumn{3}{c}{ Help-Seekers Perceived Support } \\
& $\underline{\text { Step } 1}$ & $\underline{\text { Step } 2}$ & $\underline{\text { Step } 3}$ \\
Control Variables & & & \\
$\quad$ Help-Seeker Tenure & -.01 & -.03 & -.02 \\
$\quad$ Help-Seeker Education Level & -.06 & -.05 & -.05 \\
$\quad$ Help-Seeker Job Satisfaction & $.22 *$ & $.21 *$ & $.22 *$ \\
$\quad$ Network Alter Affect-Based Trust & $.21 *$ & $.20 *$ & $.19^{*}$ \\
Predictors & & & \\
$\quad$ Network Alter Individualism & & $.22 *$ & $.19^{*}$ \\
$\quad$ Network Density & & -.01 & -.01 \\
Interactions & & & $.23 *$ \\
$\quad$ Network Individualism X Network Density & $2.39+$ & $2.57 *$ & $3.27^{* *}$ \\
$\mathrm{~F} \quad$ & .09 & .13 & .19 \\
$\mathrm{R}^{2}$ & $.09+$ & $.05+$ & $.05 *$ \\
$\Delta \mathrm{R}^{2}$ & &
\end{tabular}

Standardized coefficients reported. $\Delta R^{2}$ report change from the previous model. Two-tailed tests are reported. $+p<0.10 ;{ }^{*} p<0.05 ; * * p<0.01$.

In support of Hypothesis 2, the effect of network individualism on help-seekers' perceived support was moderated by network density. The change in $R^{2}$ from Step 2 to Step 3 was statistically significant $\left(\Delta R^{2}=.05, \Delta F(1,99)=6.54, p<.05\right)$ as was the interaction term $(B$ $=.23, t=2.56, p<.05)$. A simple slopes analysis was conducted and the relationship is plotted in Figure 1. As seen in the figure, the relationship between network individualism and perceived support is positive and significant in high density help-seeking networks $(+1 S D ; B$ $=.37, t=3.72, p<.01)$, but non-significant in low density help-seeking networks. 


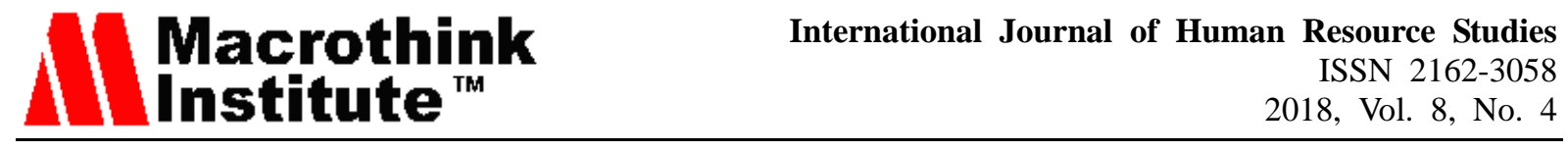

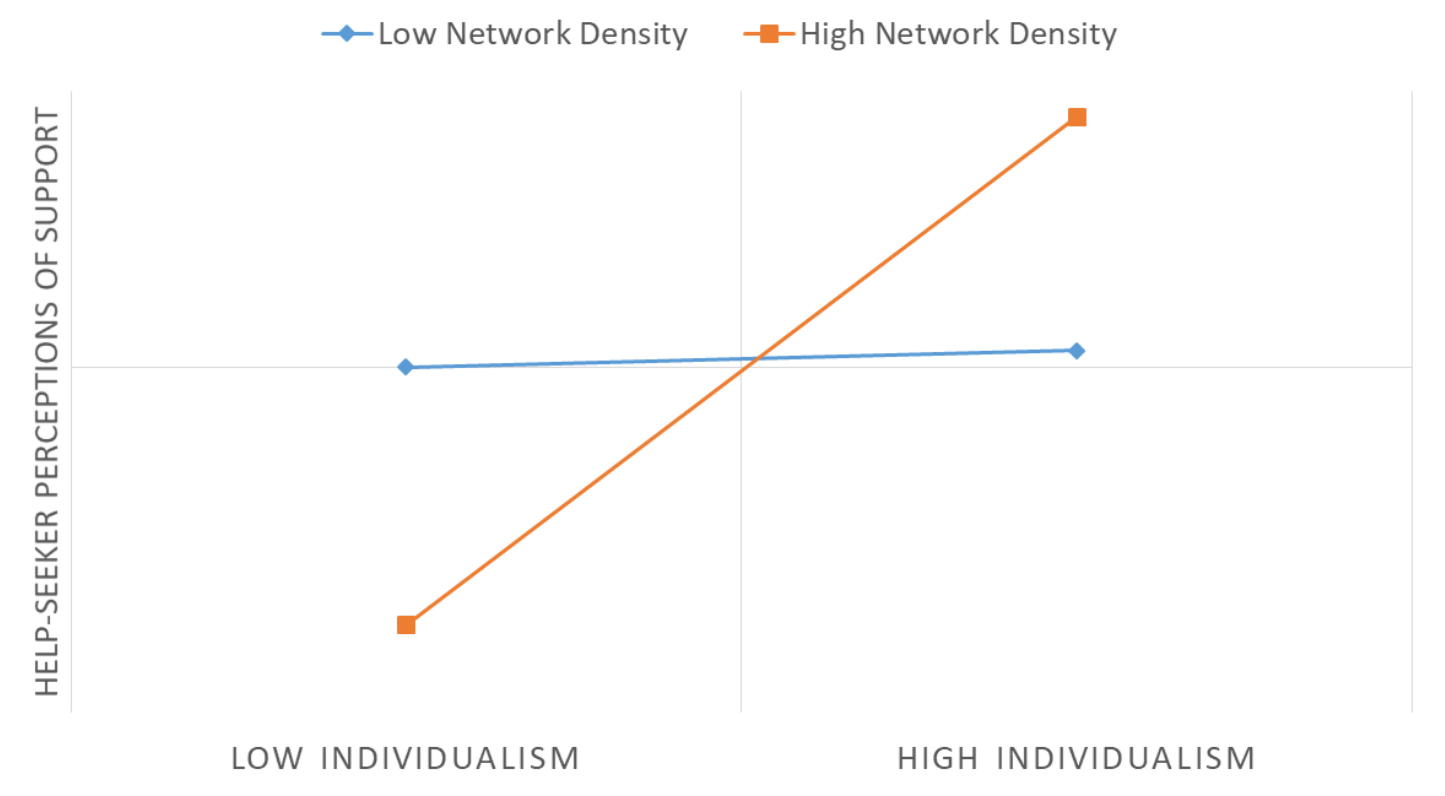

Figure 1. Plot of the Effect on Help-Seekers' Perceived Support of the Interaction between Network Density and Network Individualism.

\section{Discussion}

In this study, we examined individualism within employee help-seeking networks. We hypothesized that help-seeking networks are a potent, incentive-laden social context that is salient for individuals with active personal identities, and as a result, the level of individualism within an employee's help-seeking network is positively related to that employee's perception of support (Hypothesis 1). Support for the hypothesis was found. Help-seeking networks provide opportunities for individualists to demonstrate skill as a problem-solver and to receive the type of personal recognition that can lead to future career advancement. Additionally, helping interactions enhance self-worth when the personal identity is active because positive evaluations of the self (as help-giver) compared to the plight of the other (as help-seeker) are easily made (e.g., interdependence vs. dependence, strength vs. vulnerability, competence vs. incompetence, etc.).

In support of Hypothesis 2, we found the relationship between individualism and perceptions of support to be moderated by network density; individualism was a stronger predictor of help-seekers' perceptions of support in dense help-seeking networks. Help-seeking networks are constituted by role-based helping relationships (i.e., help-giver, help-seeker) and present a salient context that primes the activation of relational identities. Further, dense networks are likely to amplify the salience of role-based identities to the extent that cooperative engagement and the performance of other-focused behaviors become part of how network members define themselves. Finding a significant interaction between individualism and network density provides support for a relational-identity explanation of the link between individualism and helping behavior. Because the main effect of network help-givers' individualism was not reduced to non-significance upon entry of the interaction term, it is possible that both a personal identity orientation and a relational identity orientation is active 
in help-seeking networks. Future research should investigate how various structural features of help-seeking networks differentially prime personal and relational identities.

Interestingly, network individualism explained variance in perceived support beyond that explained by the level of affect-based trust. Flynn (2005) suggests that individualists' connections with help-seekers resemble negotiated exchange. Representing one of several forms of interpersonal exchange, negotiated exchange is characterized by a focus on the protection of self-interest, whereby episodes of exchange are direct and explicit (e.g., quid pro quo; "I'll work your shift this week if you work mine next week"). The explicitness of exchange facilitates monitoring of "repayment" to satisfy outstanding debts (Jensen \& Meckling, 1976; Klein, 1993). Negotiated exchanges are calculative and generally devoid of affect. Further, the inherent transparency of the exchange provides for clear evaluations of personal ability compared to others. Because affect-based trust is an indicator of high-quality social exchange connections, this finding suggests that helping interactions may also resemble less affect-based connections.

\subsection{Implications}

We believe this study makes several significant contributions to the literature. First, employee helping behavior has received a considerable amount of research attention as a dimension of organizational citizenship behavior (e.g., Lepine \& Van Dyne, 2001; Settoon \& Mossholder, 2002; Van Scotter \& Motowidlo, 1996; Williams \& Anderson, 1991). However, studies investigating the relationship between individualism and helping behavior have produced mixed results. Early citizenship behavior research found individualists to engage in helping interactions to a lesser extent then collectivists. Interestingly, citizenship behavior studies focus almost exclusively on the act of giving help. As noted, help-seekers often initiate helping interactions. Because individualists are not inclined to engage in "spontaneous" help-giving, the generalizability of those studies is limited. The findings of our study highlights the importance of accounting for context and the dynamics of interpersonal connections when testing theoretical relationships.

The findings of this study have several implications for organizations attempting to maximize the potential of informal employee networks. First, organizations can take measures to ensure that the potential of employee informal networks is realized (Krackhardt \& Hanson, 1993). For employees with individualistic orientations, organizations can incentivize features of individualists' task and social environment to produce cooperative engagement. Our findings suggest that clear, unambiguous links between individual rewards and the effective fulfillment of salient roles within role-based relationships will lead individualists to higher levels of cooperative engagement.

Incentives can be established that encourage participation in help-giving roles, such as recognition for providing unique solutions to problems, credit for the amount of time spent outside normal work hours in the course of providing assistance, etc. Organizations might implement collaborative IT applications that provide a robust means for coworkers to connect with each other, to publicize skills, abilities, interests and other helping resources, and to facilitate efficient and direct communication among coworkers where solicitations for help 
can be made, help-givers and help-seekers matched, and solutions generated and documented. Through this documentation, management can build a knowledge base that tracks and evaluates the effectiveness of networks.

More generally, organizations can formalize aspects of certain types of informal networks. Employee can be encouraged to build effective networks. Where appropriate, informal roles and role-based relationships can be identified and more clearly articulated. Further, qualitative assessment of network composition (e.g., "Who's in the network and what talents do they have?") and structure (i.e., "Does the network's structure promote efficiency and effectiveness?" "Is it structured so as to best support the purpose for which it exists?") can be used to periodically evaluate its capacity to add value for employee and organizational performance.

\subsection{Limitations}

The implications of our results must be considered in light of the limitations of our research. First, we assumed that the nomination of a help-giver by a help-seeker indicated the presence of a valued helping connection; one that provides instrumental assistance. It is possible that those connections were multiplex - providing among other things, friendship, liking and socio-emotional support. While we controlled for the potential influence of friendship and liking on perceptions of support (i.e., affect-based trust), future research should examine the relationship between individualism and perceptions of support in other types of networks. Second, we suggested that individualists would be seen as an important network resource due to their motivation and competence for creative problem-solving. These were central to our hypotheses but not measured. Future research should test this assumption.

Finally, future studies should conduct longitudinal studies to investigate the changes of help-seeking networks over time. Individualists' participation in help-seeking networks are likely to be impermanent and non-intensive (Oyserman, 1993). In other words, individualists focus on balancing the costs and benefits of connections and otherwise on the extent to which they competently and successfully fulfill a role. They will exit connections when the costs exceed the benefits. In the current study, the connections identified by respondents were assumed to be enduring; that they reflected a history of successful helping interactions and a consensus on the part of network members that they were worthy of being sustained. Although it is possible that the connections were, it is possible that they weren't. Longitudinal studies will provide important insight into how informal network connections emerge, are sustained, and are terminated.

\section{Conclusion}

This study examined individualism within the context of help-seeking networks. We found employees to report higher levels of support when their help-seeking networks are characterized by high levels of individualism. Further, we found that the relationship is stronger in dense networks. We discussed the results and provided implications for theory, research and practice. 


\section{References}

Adler, P., \& Kwon, S. (2002). Social capital: Prospects for a new concept. The Academy of Management Review, 27, 17-40. https://doi.org/10.5465/amr.2002.5922314

Aiken, L. S., \& West, S. G. (1991). Multiple regression: Testing and interpreting interactions. Newbury Park, CA: Sage.

Allik, J., \& Realo, A. (2004). Individualism-collectivism and social capital. Journal of Cross-Cultural Psychology, 35, 29-49. https://doi.org/10.1177/0022022103260381

Alpert, S., Ashforth, B., \& Dutton, J. (2000). Organizational identity and identification: Charting new waters and building new bridges. Academy of Management Review, 25, 13-18. https://doi.org/10.5465/amr.2000.2791600

Ames, R., \& Lau, S. (1982). An attributional analysis of help-seeking in academic settings. Journal of Educational Psychology, 74, 414-423. https://doi.org/10.1037/0022-0663.74.3.414

Anderson, S. E., \& Williams, L. J. (1996). Interpersonal, job, and individual factors related to helping processes at work. Journal of Applied Psychology, 81, 282-296. https://doi.org/10.1037/0021-9010.81.3.282

Ashforth, B. E. (2001). Role transitions in organizational life: An identity-based perspective. Mahwah, NJ: Lawrence Erlbaum Associates.

Baer, M., Oldham, G. R., \& Cummings, A. (2003). Rewarding creativity: When does it really matter? The Leadership Quarterly, 14, 569-586. https://doi.org/10.1016/S1048-9843(03)00052-3

Bamberger, P. A. (2009). Employee help-seeking: Antecedents, consequences and new insights for future research. Research in Personnel and Human Resources Management, 28, 49-98. https://doi.org/10.1108/S0742-7301(2009)0000028005

Batson, C. D. (1994). Why act for the public good? Four answers. Personality and Social Psychology Bulletin, 20, 603-610. https://doi.org/10.1177/0146167294205016

Blumer, H. (1969). Symbolic interactionism: Perspective and method. Englewood Cliffs, NJ: Prentice-Hall.

Bolino, M. C., \& Turnley, W. H. (2005). The personal costs of citizenship behavior: The relationship between individual initiative and role overload, job stress, and work-family $\begin{array}{llllll}\text { conflict. Journal of Applied Psychology, } & 90, & 740 & -748 .\end{array}$ https://doi.org/10.1037/0021-9010.90.4.740

Bolino, M. C., Turnley, W. H., \& Bloodgood, J. M. (2002). Citizenship Behavior and the Creation of Social Capital in Organizations. The Academy of Management Review, 27, 505-522. https://doi.org/10.5465/amr.2002.7566023

Borgatti, S., Everett, M., \& Freeman, L. (2002). UCINET for Windows: Software for social network analysis. Harvard, MA: Analytic Technologies. 
Bowler, W., \& Brass, D. (2006). Relational correlates of interpersonal citizenship behavior: A social network perspective. Journal of Applied Psychology, 91, 70-82. https://doi.org/10.1037/0021-9010.91.1.70

Brayfield, A., \& Rothe, H. (1951). An index of job satisfaction. Journal of Applied Psychology, 35, 307-311. https://doi.org/10.1037/h0055617

Brewer, M. B., \& Gardner, W. (1996). Who is this "we"?: Levels of collective identity and self-representations. Journal of Personality and Social Psychology, 71, 83-93. https://doi.org/10.1037/0022-3514.71.1.83

Brickson, S. (2000). The impact of identity orientation on individual and organizational outcomes in demographically diverse settings. The Academy of Management Review, 25, 82-101. https://doi.org/10.5465/amr.2000.2791604

Cammann, C., Fichman, M., Jenkins, G., \& Klesh, J. (1983). Assessing the attitudes and perceptions of organizational members. In S. Seashore, E. Lawler, P. Mirvis, \& C. Cammann (Eds.), Assessing organizational change, 71-138. New York: Wiley.

Chatman, J., \& Flynn, F. (2001). The influence of demographic heterogeneity on the emergence and consequences of cooperative norms in work teams. Academy of Management Journal, 44, 956-974.

Clary, E. G., \& Snyder, M. (1999). The motivations to volunteer: Theoretical and practical considerations. Current Directions in Psychological Science, 8, 156-159. https://doi.org/10.1111/1467-8721.00037

Coleman, J. S. (1990). Foundations of social theory. Cambridge, MA: Harvard University Press.

Dukerich, J., Golden, B., \& Shortell, S. (2002). Beauty is in the eye of the beholder: The impact of organizational identification, identity, and image on the cooperative behaviors of physicians. Administrative Science Quarterly, 47, 507-533. https://doi.org/10.2307/3094849

Earley, P. C. (1993). East meets West meets Mideast: Further explorations of collectivistic and individualistic work groups. Academy of Management Journal, 36, 319-348.

Eisenberger, R., Huntington, R., Hutchison, S., \& Sowa, D. (1986). Perceived organizational support. Journal of Applied Psychology, 71, 500-507.

Fischer, E. H., Winer, D., \& Abramowitz, S. I. (1983). Seeking professional help for psychological problems. In A. Nadler, J. D. Fisher, \& B. M. DePaulo (Eds.), New directions in helping. New York: Academic Press.

Flynn, F. J. (2005). Identity orientations and forms of social exchange in organizations. Academy of Management Review, 30, 737-750. https://doi.org/10.5465/amr.2005.18378875

Flynn, F. J., Chatman, J. A., \& Spataro, S. A. (2001). Getting to know you: The influence of personality on the impression formation and performance of demographically different people in organizations. Administrative Science Quarterly, 46, 414-442. 
https://doi.org/10.2307/3094870

Gardner, W., Gabriel, S., \& Hochschild, L. (2002). When you and I are "we," you are not threatening: The role of self-expansion in social comparison. Journal of Personality and Social Psychology, 82, 239-251. https://doi.org/10.1037/0022-3514.82.2.239

Gelfand, M. J., Triandis, H. C., \& Chan, D. (1996). Individualism versus collectivism or versus authoritarianism? European Journal of Social Psychology, 26, 397-410. https://doi.org/10.1002/(SICI)1099-0992(199605)26:3<397::AID-EJSP763>3.0.CO;2-J

Goncalo, J., \& Staw, B. (2006). Individualism-collectivism and group creativity. Organizational Behavior and Human Decision Processes, 100, 96-109. https://doi.org/10.1016/j.obhdp.2005.11.003

Granovetter, M. S. (1973). The strength of weak ties. American Journal of Sociology, 78, 1360-1380. https://doi.org/10.1086/225469

Gundlach M., Zivnuska, S., \& Stoner, J. (2006). Understanding the relationship between individualism-collectivism and team performance through an integration of social identity theory and the social relations model. Human Relations, 59, 1603-1632. https://doi.org/10.1177/0018726706073193

Haslam, S., Powell, C., \& Turner, J. (2001). Social identity, self-categorization, and work motivation: Rethinking the contribution of the group to positive and sustainable organizational outcomes. Applied Psychology, $49, \quad 319 \quad$ - 339. https://doi.org/10.1111/1464-0597.00018

Hogg, M. A., \& Terry, D. (2000). Social identity and self-categorization processes in organizational contexts. Academy of Management Review, 25, 121-140. https://doi.org/10.5465/amr.2000.2791606

Hosking, D. M., Dachler, H. P., \& Gergen, K. J. (1995). Management and organization: Relational alternatives to individualism. Aldershot, UK: Avebury.

Iverson, R. D. (1999). An event history analysis of employee turnover: The case of hospital employees in Australia. Human Resource Management Review, 9, 397- 418. https://doi.org/10.1016/S1053-4822(99)00027-3

Jensen, M. C., \& Meckling, W. H. (1976). Theory of the firm: Managerial behavior, agency costs, and ownership structure. Journal of Financial Economics, 3, 305-360. https://doi.org/10.1016/0304-405X(76)90026-X

Kilduff, M., \& Tsai, W. (2003). Social Networks and Organizations. SAGE Publications Limited. https://doi.org/10.4135/9781849209915

Kirkman, B. L., \& Shapiro, D. L. (1997). The impact of cultural values on employee resistance to teams: Toward a model of globalized self-managing work team effectiveness. The Academy of Management Review, 22, 730-757.

Kirkman, B. L., \& Shapiro, D. L. (2000). Understanding why team members won't share? 
Small Group Research, 31, 175-209. https://doi.org/10.1177/104649640003100203

Kirton, M. J. (Ed.). (1989). Adaptors and Innovators: Styles of creativity and problem-solving. London: Routledge.

Klein, B. (1993). Contracts and incentives: The role of contract terms in assuring performance. In L. Werin \& H. Wijkander (Eds.), Contract economics, (pp. 149 -172). Cambridge, MA: Blackwell.

Konovsky, M. A., \& Pugh, S. D. (1994). Citizenship behavior and social exchange. Academy of Management Journal, 37, 656-669.

Krackhardt, D., \& Hanson, J. (1993). Informal networks: the company behind the chart. Harvard Business Review, 71, 104-111.

Lawler, E., \& Yoon, J. (1993). Power and the emergence of commitment behavior in negotiated exchange. American Sociological Review, 58, 465- 481. https://doi.org/10.2307/2096071

Leana, C., \& van Buren, H. (1999). Organizational social capital and employment practices. The Academy of Management Review, 24, 538-555. https://doi.org/10.5465/amr.1999.2202136

Lee, F. (1997). When the going gets tough, do the tough ask for help? Help seeking and power motivation in organizations. Organizational Behavior and Human Decision Processes, 72, 336-363. https://doi.org/10.1006/obhd.1997.2746

LePine, J., \& Van Dyne, L. (2001). Voice and cooperative behavior as contrasting forms of contextual performance: Evidence of differential relationships with big five personality characteristics and cognitive ability. The Journal of Applied Psychology, 86, 326-336. https://doi.org/10.1037/0021-9010.86.2.326

Liu, D., Chen, X. P., \& Holley, E. (2017). Help yourself by helping others: The joint impact of group member organizational citizenship behaviors and group cohesiveness on group member objective task performance change. Personnel Psychology, 70, 809-842. https://doi.org/10.1111/peps.12209

Locke, E. A. (1976). The nature and causes of job satisfaction. In M. D. Dunnette, Handbook of Industrial and Organizational Psychology, 1, 1297-1343.

Marcus, J., \& Le, H., (2013). Interactive effects of levels of individualism-collectivism on cooperation: A meta-analysis. Journal of Organizational Behavior, 34, 813-834. https://doi.org/10.1002/job.1875

Markus, H., \& Kitayama, S. (1991). Culture and the self: Implications for cognition, emotion, $\begin{array}{lllll}\text { and motivation. } & \text { Psychological Review, } & 98, & 224 & -253 .\end{array}$ https://doi.org/10.1037/0033-295X.98.2.224

McAllister, D. J. (1995). Affect- and cognition-based trust as foundations for interpersonal cooperation in organizations. Academy of Management Journal, 38, 24-59. 
Moorman, R. H., \& Blakely, G. L. (1995). Individualism-collectivism as an individual difference predictor of organizational citizenship behavior. Journal of Organizational Behavior, 16, 127-142. https://doi.org/10.1002/job.4030160204

Nadler, A. (1998). Relationships, esteem and achievement perspectives on autonomous and dependent help seeking. In S. Karabenick, Strategic help seeking: Implications for knowledge acquisition (pp. 1-57). Mahwah, NJ: Erlbaum Publishing Co.

Ocampo, L., Acedillo, V., Bacunador, A., Balo, C., Lagdameo, Y., \& Tupa, N. (2018). A historical review of the development of organizational citizenship behavior (OCB) and its implications for the twenty-first century. Personnel Review, 47, 821-862. https://doi.org/10.1108/PR-04-2017-0136

Oh, H., Chung, M. H., \& Labianca, G. (2004). Group social capital and group effectiveness: The role of informal socializing ties. Academy of Management Journal, 47, 860-875. https://doi.org/10.5465/20159627

Oyserman, D. (1993). The lens of personhood: Viewing the self and others in a multicultural society. Journal of Personality and Social Psychology, 65, 993-1009. https://doi.org/10.1037/0022-3514.65.5.993

Oyserman, D., Coon, H. M., \& Kemmelmeier, M. (2002). Rethinking individualism and collectivism: Evaluation of theoretical assumptions and meta-analyses. Psychological Bulletin, 128, 3-72. https://doi.org/10.1037/0033-2909.128.1.3

Perry, B., Pescosolido, B, \& Borgatti, S. (2018). Egocentric network analysis: Foundations, methods, and models. Cambridge University Press. https://doi.org/10.1017/9781316443255

Podsakoff, N. P., Whiting, S. W., Podsakoff, P. M., \& Blume, B. D. (2009). Individual- and organizational-level consequences of organizational citizenship behaviors: A meta-analysis. Journal of Applied Psychology, 94, 122-141. https://doi.org/10.1037/a0013079

Ramamoorthy, N., \& Flood, P. C. (2004). Individualism/collectivism, perceived task interdependence and teamwork attitudes among Irish blue-collar employees: A test of the main and moderating effects. Human Relations 57, 347-366. https://doi.org/10.1177/0018726704043274

Reagans, R., \& Zuckerman, E. W. (2001). Networks, diversity, and productivity: The social capital of corporate R\&D teams. Organization Science, 12, 502-517. https://doi.org/10.1287/orsc.12.4.502.10637

Rhoades, L., \& Eisenberger, R. (2002). Perceived organizational support: A review of the $\begin{array}{lllll}\text { literature. Journal of } \quad \text { Applied } & \text { Psychology, } & 87, & \text { 698-714. }\end{array}$ https://doi.org/10.1037/0021-9010.87.4.698

Schroeder, D. A., Penner, L. A., Dovidio, J. F., \& Piliavin, J. A. (1995). The psychology of helping and altruism: Problems and puzzles. New York: McGraw-Hill.

Schwartz, S. (1990). Individualism-collectivism: critique and proposed refinements. Journal 
of Cross-Cultural Psychology, 21, 139-157. https://doi.org/10.1177/0022022190212001

Settoon, R. P., \& Mossholder, K. W. (2002). Relationship quality and relationship context as antecedents of person- and task-focused interpersonal citizenship behavior. Journal of Applied Psychology, 87, 255-267. https://doi.org/10.1037/0021-9010.87.2.255

Settoon, R. P., Bennett, N., \& Liden, R. C. (1996). Social exchange in organizations: Perceived organizational support, leader-member exchange, and employee reciprocity. Journal of Applied Psychology, 81, 219-227. https://doi.org/10.1037/0021-9010.81.3.219

Shore, L. M., \& Wayne, S. J. (1993). Commitment and employee behavior: Comparison of affective commitment and continuance commitment with perceived organizational

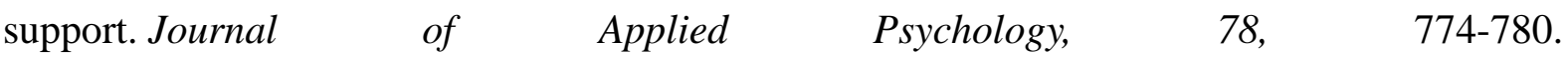
https://doi.org/10.1037/0021-9010.78.5.774

Sluss, D., \& Ashforth, B. (2007). Relational identity and identification: Defining ourselves through work relationships. Academy of Management Review, 32, 9-32. https://doi.org/10.5465/amr.2007.23463672

Sparrowe, R. T., Liden, R. C., Wayne, S. J., \& Kraimer, M. L. (2001). Social networks and the performance of individuals and groups. The Academy of Management Journal, 44, 316-325.

Triandis, H. C. (1995). Individualism and collectivism. Boulder, CO: Westview.

Van Dyne, L., Vandewalle, D., Kostova, T., Latham, M. E., \& Cummings, L. L. (2000). Collectivism, propensity to trust and self-esteem as predictors of organizational citizenship in a non-work setting. Journal of Organizational Behavior, 21, 3-23. https://doi.org/10.1002/(SICI)1099-1379(200002)21:1<3::AID-JOB47>3.0.CO;2-6

Van Scotter, J. R., \& Motowidlo, S. J. (1996). Interpersonal facilitation and job dedication as separate facets of contextual performance. Journal of Applied Psychology, 81, 525-531. https://doi.org/10.1037/0021-9010.81.5.525

Wagner, J. A. (1995). Studies of individualism-collectivism: Effects on cooperation in groups. Academy of Management Journal, 38, 152-172.

Wasserman, S., \& Faust, K. (1994). Social network analysis: Methods and applications. Cambridge: Cambridge University Press. https://doi.org/10.1017/CBO9780511815478

Williams, L. J., \& Anderson, S. E. (1991). Job satisfaction and organizational commitment as predictors of organizational citizenship and in-role behaviors. Journal of Management, 17, 601-617. https://doi.org/10.1177/014920639101700305

Zimet, G., Dahlem, N. W., Zimet, S. G., \& Farley, G. K. (1988). The multidimensional scale of perceived social support. Journal of Personality Assessment, 52, 30-41. https://doi.org/10.1207/s15327752jpa5201_2 


\section{Copyright Disclaimer}

Copyright for this article is retained by the author(s), with first publication rights granted to the journal.

This is an open-access article distributed under the terms and conditions of the Creative Commons Attribution license (http://creativecommons.org/licenses/by/4.0/). 